NBER WORKING PAPER SERIES

CAPITAL INFLOWS AND RESERVE ACCUMULATION: THE RECENT EVIDENCE

\author{
Carmen M. Reinhart \\ Vincent R. Reinhart \\ Working Paper 13842 \\ http://www.nber.org/papers/w13842
NATIONAL BUREAU OF ECONOMIC RESEARCH
1050 Massachusetts Avenue
Cambridge, MA 02138
March 2008

Presented at the Korea Institute for International Economic Policy conference, "Capital Flows, Macroeconomic Management and Regional Cooperation in Asia," where we benefited from the comments of our discussant, Prakash Loungani, and other participants. An earlier version was presented at the Konstanz Seminar on Monetary Policy and Theory, and we appreciate the comments of our discussant, Patrick Minford, and other participants. April Gifford and Meagan Berry provided excellent research support. The views expressed herein are those of the author(s) and do not necessarily reflect the views of the National Bureau of Economic Research.

NBER working papers are circulated for discussion and comment purposes. They have not been peerreviewed or been subject to the review by the NBER Board of Directors that accompanies official NBER publications.

(C) 2008 by Carmen M. Reinhart and Vincent R. Reinhart. All rights reserved. Short sections of text, not to exceed two paragraphs, may be quoted without explicit permission provided that full credit, including ( $)$ notice, is given to the source. 
Capital Inflows and Reserve Accumulation: The Recent Evidence

Carmen M. Reinhart and Vincent R. Reinhart

NBER Working Paper No. 13842

March 2008

JEL No. E0,F0,F3

\begin{abstract}
$\underline{\text { ABSTRACT }}$
Over the past decade, policymakers in many emerging market economies have opted to limit fluctuations of the value of their domestic currencies relative to the U.S. dollar. A simple interest-parity relationship is used to identify the potential sources of upward pressure on the value of a foreign exchange rate and to explain the policy options to damp them. The paper then documents the extent to which the accumulation of foreign exchange reserves has been sterilized and provides a comprehensive list of major policy initiatives related to stemming forces that would otherwise appreciate the exchange rate in over one hundred countries. This examination of policy efforts shows that a wide variety of tools are used in the attempt to stem the tide of capital flows.
\end{abstract}

Carmen M. Reinhart

University of Maryland

School of Public Policy and Department of Economic

4105 Van Munching Hall

College Park, MD 20742

and NBER

creinhar@umd.edu

Vincent R. Reinhart

American Enterprise Institute

1150 Seventeenth Street, N.W.

Washington, DC 20036

vincent.reinhart@aei.org 


\section{Capital Inflows and Reserve Accumulation: The Recent Evidence}

\section{Introduction}

Over the past decade, policymakers in many emerging market economies have opted to limit fluctuations of the value of their domestic currencies relative to the currency of some key trading partners, quite often the U.S. dollar. Two notable features have emerged from this experience. First, the ability to limit fluctuations in the exchange rate is decidedly asymmetric: Authorities have a variety of tools to blunt pressures that would otherwise lead to an appreciation of the home currency. Efforts to stem a depreciation of the home currency, in contrast, typically run aground against a strong tide of investor unwillingness to hold an asset expected to decline in value. This asymmetry requires a different analytic emphasis in addressing policy choices to counter appreciation versus depreciation. Second, policymakers seldom rely on a single means to control the exchange rate. This follows because most authorities are loathe to undertake the surest mechanism to eliminate bilateral exchange rate fluctuations-surrendering monetary autonomy to the anchor country. Instead, they make do with a combination of taxes and fees, outright controls, and exchange market intervention.

In this paper, we apply these two observations to ask: What are the tools available to authorities in emerging market economies to counter pressure on the exchange rate to appreciate? As is evident from some of our earlier work, one of the most interesting manifestations of this exchange-rate pressure comes in the form of 
capital inflows (as in Calvo, Leiderman, and Reinhart, 1996, and Reinhart and Reinhart, 1998). So we could have also posed the question as: How can authorities stem the tide of large capital inflows?

We will use a simple interest-parity relationship to identify the potential sources of upward pressure on the value of a foreign exchange rate in the next section. The section also updates some of the analysis in Calvo and Reinhart (2002) to establish that exchanges rates, even though they are subject to a variety of pressures, vary very little in practice, thereby providing some circumstantial evidence that authorities work to smooth them. But how? Variations in international reserves appear to be an important tool, but not the exclusive one.

In Section 3, the parity condition will be applied to explain the various policy options to damp exchange rates in principle. The section that follows turns to practice by considering the extent to which the accumulation of foreign exchange has effectively been sterilized and then details major policy initiatives related to stemming forces to appreciate the exchange rate in scores of countries over the past two decades. This has proved to be the most daunting aspect of this project, in that so many different countries have moved at so many different margins. Consider, for instance, China: In the past year, authorities on several occasions have raised deposit and lending rates, widened the acceptable range of variation in the yuan, raised reserve requirements, and taken efforts to encourage outflows. The fifth section offers concluding comments. 


\section{Varieties of Upward Pressure on the Exchange Value of a Currency}

Although economists' ability to explain, let along predict, movements in foreign exchange values has been shown to be dreadful, the profession retains a touching faith in a simple relationship's ability to do so. That is, uncovered interest parity remains the workhorse of exchange-rate determination in theoretical models despite its consistently poor showing in empirical derbies. By dint of necessity, we will also ride that horse to explain forces tending to put upward pressure on the exchange value of the currency of the sort associated with large capital inflows.

Adopt, for the moment, the perspective of an investor in an emerging market economy who faces two alternatives — an investment at home with a stated nominal return of $i$ in the home currency and an investment abroad with a stated return of $i *$ in the foreign currency. Let s be the foreign currency value of one unit of the home currency. The domestic asset is taxed at the rate $t^{\mathrm{D}}$ and subject to expropriation risk of $\delta$ per annum relative to the securities issued by the anchor-currency country. ${ }^{1}$ Thus, the relevant return on the domestic asset is:

$$
i-t^{D}-\delta
$$

If the domestic investor opts for holding the foreign asset, the nominal return must be translated into domestic currency, which might be expected to change over the

\footnotetext{
1 See Reinhart (2000) for a discussion of the distinction between a tax on holding an asset and on acquiring an asset. The former is akin to a reserve requirement (without remuneration) and the latter is a Tobin $\operatorname{tax}$.
} 
relevant at the rate $\dot{s} / s$, and a tax $t^{\mathrm{F}}$ is levied by the home or foreign government. ${ }^{2}$

Thus, the all-in return from the foreign asset will be:

$$
i^{*}-\frac{\dot{s}}{s}-t^{F} .
$$

The return from these two investment strategies should equal, adjusted for differences in their riskiness. This risk premium, $\rho$, is essentially defined by the difference in these all-in returns, or

$$
i-t^{D}-\delta=\rho+i^{*}-t^{F}-\frac{\dot{s}}{s}
$$

This identity can be useful in describing pressures on the exchange rate, with the equal sign serving as the fulcrum to balance relative asset demands if we move from treating this equation as an identity to treating it as a behavioral relationship. That is, think of the risk premium as parametric instead of as a residual. Upward impetus to the exchange value of the currency might materialize for three key reasons:

1. The foreign interest rate falls. All else equal, a reduction in the foreign interest rate would tend to increase relative demands for the home asset, inducing home-exchange rate appreciation. This force came prominently to the fore in two recent episodes when the U.S. Federal Reserve cut its policy interest rate to unusually low levels, to 3 percent in nominal terms in 1992 and to 1 percent from 2003. These

\footnotetext{
2 Either rule out default by the foreign sovereign or interpret $\delta$ as differential default risk. The "•" Operator denotes the forward derivative with respect to time and, to keep the notation simple, we abstract from uncertainty.
} 
low returns encouraged investors to seek alternatives, often riskier and sometimes off the shores of the United States. Calvo, Leiderman, and Reinhart (1996) identified the low levels of U.S. interest rates as instrumental in explaining capital flows. In updating this approach, Reinhart and Reinhart (2002) found systematically that real private capital flows, direct investment, and portfolio investment to emerging market economies did indeed vary inversely with the nominal short-term U.S. interest rate over the last thirty years of the twentieth century.

2. Default risk declines. An improvement in economic conditions and fiscal consolidation are often associated with upward pressures on the value of an emerging market economy's currency. Within the framework provided by the parity condition, this can be explained as a reduction in differential default risk. This has been evident in episodes in countries where the exchange rate rallied on news of improvement in the fiscal accounts, on the announcement of structural reform, and when outside assessors—-i.e., the rating agencies—release an improved evaluation. Indeed, the association between rising commodity prices and an appreciating currency in emerging market economies that has sometimes been noted might be thought as reflecting the more complicated causal chain in which gains in commodity prices improve fiscal conditions and thereby trim default risk. ${ }^{3}$

3. Risk appetites increase. Instances of increased tolerance and/or perception of lessened risk on the part of global investors tend to be associated with

\footnotetext{
3 Chen and Rogoff (2002), for instance, found robust empirical relationships linking the exchange rates of Australia, Canada, and New Zealand and country-specific indexes of commodity prices.
} 
the search for return by global investors and capital inflows to emerging markets. In the United States, for instance, narrow domestic corporate yield spreads in the early and mid 1990s, elevated stock prices in the late 1990s, and low financial market volatilities of 2005 and 2006 all apparently served to encourage private capital inflows. In terms of the parity condition, such increased enthusiasm for emerging market assets maps into a reduction in the risk premium. And all else equal, such a decline would be associated with the expectation of an appreciation of the exchange rate.

We have pushed and pulled the interest parity condition to identify reasons why the exchange rate might change. In the event, many exchange rates do not move much. The joint observations that there seem to be many sources of potential pressures on the exchange rate in principle and the lack of exchange rate volatility in practice creates the strong presumption that authorities often take steps to limit exchange rate fluctuations. In other work, one of us has dubbed this "the fear of floating" (Calvo and Reinhart, 2002). This reluctance to allow market forces to take their course has had various rationales, including the concerns that a surge in capital flows may distort relative prices, exacerbate weaknesses in the financial sector, and feed asset price bubbles. Such concerns tend to be especially acute if authorities view the favor of financial markets to be fleeting. Deterring such "hot money" may be seen as a means of smoothing through volatile foreign appetites for risk. But not all 
money is hot, and deterring foreign capital inflows presumably limits additions to the domestic capital stock, thereby reducing the resources available for production.

The evidence, at least as amassed by Calvo and Reinhart, suggests that many authorities see the balance as tilted against capital inflows. Among their calculations, the authors compute the month-to-month percent change in the exchange rate and reserves for a large set of countries. They then compared the likelihood that the exchange rate fluctuated by less and reserves by more than their chosen benchmarks (Australia, Japan, and the United States). Actual policies tended to be consistent with more muted swings in the exchange rate in most countries than in the benchmarks. And one of the instruments to achieve that outcome appears to be reserves, in that reserves generally vary by more than in any of the benchmark countries.

Figure 1 updates this analysis using the monthly percent changes in exchange rates (relative to the U.S. dollar) and international reserves (in U.S. dollars) for ninetyseven developing countries from 1990 to 2006 . The chart in the upper panel compares the mean absolute percent change in the exchange rate (along the vertical axis) with the mean absolute percent change in reserves (along the horizontal axis). The horizontal and vertical lines (at 2.1 and 4.6, respectively) represent the sample averages for Australia, a country noted for its commitment to floating exchange rates. As is evident from the chart and the contingency table in the bottom panel, seven out of ten countries in the sample had exchange rates that were less variable and reserves that were more variable than the benchmark experience. What is probably most 


\section{Figure 1}

Changes in Reserves and Exchange Rate for 98 Developing Countries, 1990-2006*

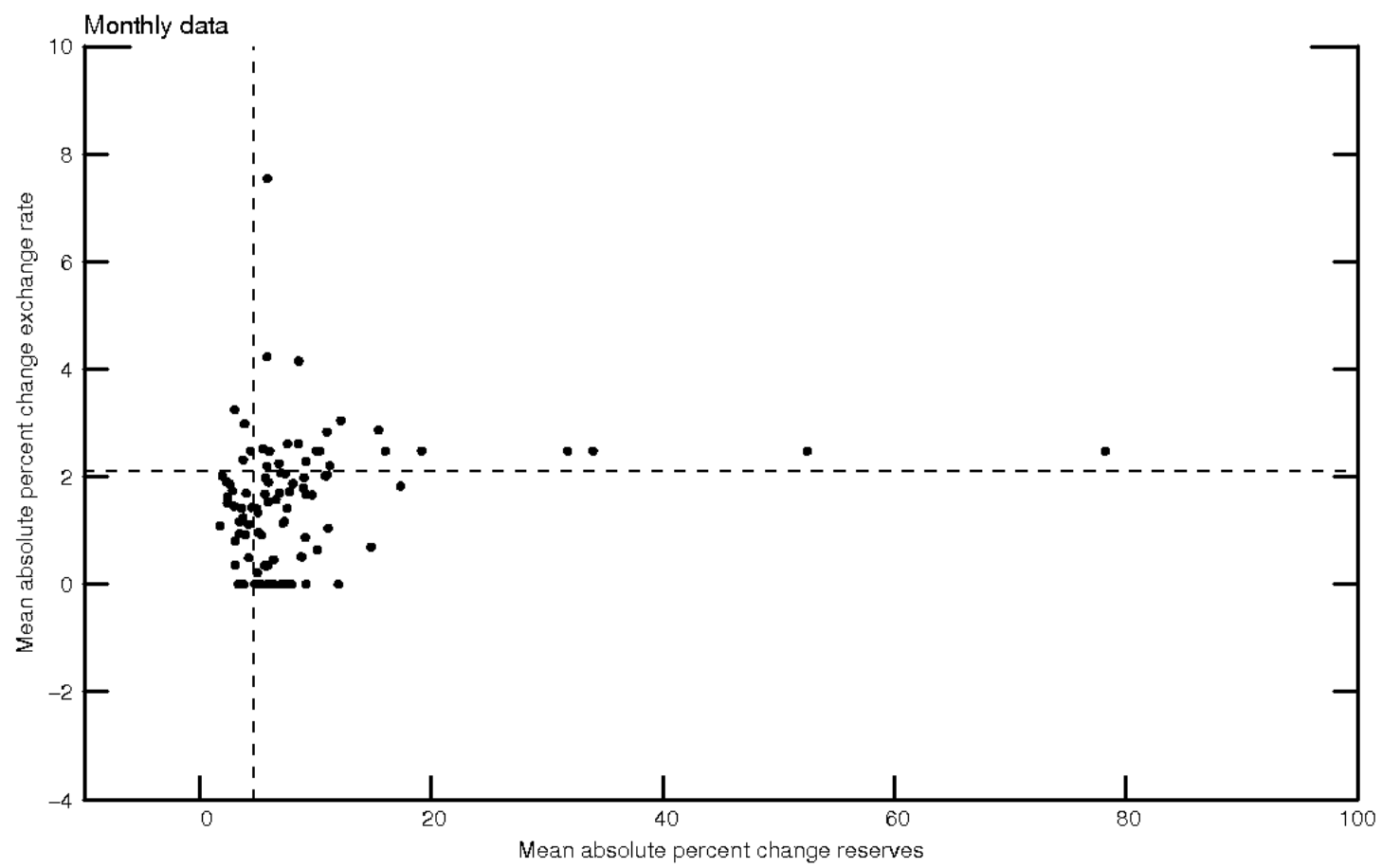

Note: Horizontal and vertical line values of 2.1 and 4.61 represent Australia's mean absolute percent change in reserves and exchange rate, respectively. Data for reserves are from line 1l.d, and for exchange rate from line ooag (in U.S. dollars, end of period), from 'International Financial Statistics' (|MF).

"Gountries used in the analysis were Algeria, Antigua Barbuda, Argentina, Bahamas, Bangladesh, Barbados, Belize, Benin, Bhutan, Bolivia, Botswana, Brazil, Burkina Faso, Burundi, Gameroon, Gape Verde, Gentral African Republic, Ghad, Ghile, Ghina, Golombia, Congo Republic, Costa Rica, Cote d'Ivoire, Gyprus, Djibouti, Dominica, Dominican Republic, Ecuador, Egypt, El Salvador, Equatorial Guinea, Ethiopia, Gabon, Gambia, Ghana, Grenada, Guatemala, Guinea Bissau, Guyana, Haiti, Honduras, Hungary, India, Indonesia Israel, Jamaica, Jordan, Kenya, Korea, Kuwait, Lebanon, Lesotho, Malaysia, Maldives, Mali, Malta, Mauritius, Mexico, Morocco, Myanmar, Netherland, Antilles, Niger, Oman, Pakistan, Panama, Papau New Guinea, Paraguay, Peru, Philippines, Poland, Qatar, Romania, Rwanda, Samoa, St. Kitts Nevis, St. Lucia, St. Vincent, Saudi Arabia, Senegal, Seychelles, Sierra Leone, Singapore, Solomon Islands, South Africa, Sri Lanka, Sudan, Suriname, Tamzania, Thailand, Togo, Tunisia, Turkey, Uganda, United Arab Emirates, Uruguay, Vanuatu, and Venezuela.

Mean absolute percent change values compared to Australia's (expressed as percentage of whole for 98 countries)

\begin{tabular}{|c|c|c|c|}
\hline \multirow{4}{*}{$\frac{\bar{c}}{\mathrm{c}}$} & & \multicolumn{2}{|c|}{ Reserves } \\
\hline & & $<4.61$ & $>=4.61$ \\
\hline & $>=2.1$ & 4.1 & 26.5 \\
\hline & $<2.1$ & 21.4 & 48.0 \\
\hline
\end{tabular}


instructive is the upper left quadrant of the graph and the contingency table. Few countries (4 percent) were willing to tolerate exchange rates that were more variable than the benchmark while varying their reserves by less than the benchmark.

Thus, policymakers in emerging market economies appear to have made the effort to limit fluctuations in exchange rates. However, if the interest rate parity condition purports to explain the determination of exchange rates, then the steps authorities take to damp currency fluctuations must leave footprints there. But that is the subject of Section 3.

\section{Tools to Limit Exchange Rate Fluctuations}

The interest parity condition offered multiple margins for authorities to offset forces that would otherwise produce an appreciation of the exchange rate. We will detail four in particular. ${ }^{4}$

1. Shadow foreign financial conditions. In principle, the domestic monetary authority could adjust the home interest rate point for point with any change in foreign financial conditions. If, for instance, the foreign monetary authority lowers its policy rate, the domestic interest rate could be moved down in tandem, thereby never allowing an incipient wedge to open up between the left and right hand sides of the parity condition that would otherwise be filled with the expectation of an exchange rate change.

$4 \quad$ Reinhart and Reinhart (1998) provide a longer list of tools. 
This, of course, is the classic recipe for an open economy to stabilize its exchange rate by surrendering its monetary autonomy. ${ }^{5}$ But in a world of potentially volatile financial flows, the issue is more complicated. Authorities in the emerging market economy must tether their policy rate to overall financial conditions, not the foreign policy rate alone. Thus, the domestic rate may have to change with changes in the perceived default rate and the risk premium, two variables that must be inferred, not observed. As a case in point, the U.S. Federal Reserve has eased its policy stance considerably of late, in part in response to a weakening domestic economy and increasing credit risk spreads associated with heightened investor skittishness. The reduction in the policy rate and the increase in risk premiums work in opposite directions on overall U.S. financial conditions, something authorities in emerging market economies have to be mindful of in calibrating their own policies. Also note that the change in the domestic interest rate can be put in place either through domestic open market operations or unsterilized foreign exchange intervention, which may have different effects on other elements of the parity condition.

2. Increase taxes on the home asset. Home authorities could always attempt to dampen the ardor of global investors for emerging market assets by raising the tax on them. ${ }^{6}$ Again, in principle, such variations could counter changes in any of

$5 \quad$ Notice that, for the anchor country, the effects of its monetary policy are amplified to the extent that other countries follow its lead. The decision of $\mathrm{N}$ countries to follow the $\mathrm{N}+1^{\text {st }}$ entails different dynamics than when $\mathrm{N}+1$ countries fix their exchange rate.

6 Edwards (1999) reviews the experience of capital controls in emerging market economies. 
the other elements of the parity condition without recourse to changes in the exchange rate. Or could they? Bartolini and Drazen (1997) caution that changes in capital controls may serve as a signal to foreign investors. Presumably, the same may be said about tax policy. Foreign investors might interpret an increase in the tax on foreigners as an attempt to preserve an attractive asset for local investors. If that is the case, then foreign investors may just pile more capital into the country. In effect, the increase in the tax rate would be offset to some extent by a reduction in perceived default risk.

3. Lower the tax on foreign assets. If capital inflows from foreigners cannot be deterred, perhaps the authorities can encourage capital outflows by domestic residents, thereby keeping net inflows unchanged (Labán and Larraín, 1993). Aside from signaling aspects just mentioned, this mechanism of lowering the tax on foreign assets is available only if there was a tax to start with, as it is unlikely authorities would go so far as subsidizing investments in their industrial country anchor.

4. Conduct sterilized intervention. If domestic and foreign assets are imperfect substitutes in investors' portfolios, then changes in relative asset shares could affect the foreign exchange risk premium, blunting pressures on the exchange rate to change. International economists have long struggled with the issue of whether this theoretical result holds in practice. Schadler et al. (1993) conclude that, in most of the developing countries that they examine, there is some scope for 
sterilization policies in the short run-i.e., changes in domestic credit are not instantly offset by changes in net foreign assets. Frankel and Okungwu (1996), however, find stronger evidence of perfect capital mobility in many of the developing countries that have experienced heavy capital inflows-casting greater doubt on any ability to influence exchange rates through sterilization.

Another line of work has argued that even if assets were perfect substitutes, sterilized intervention might serve an important role in signaling policy intentions. In effect, foreign exchange intervention might be viewed as the first step in a sequence of policy actions. In pricing foreign exchange, market participants would look past those essentially irrelevant operations to the changes in the domestic policy interest rate that they foreshadow, leading to an association between intervention and changes in currency value (Mussa, 1981). The evidence on this issue is mixed: Kaminsky and Lewis (1996) find little empirical support for the signaling hypothesis in the United States, while Dominguez and Frankel (1993) do.

It is important to realize that, given the uncertainties surrounding the efficacy of all these policies, risk-averse authorities tend not to rely on any one alone. Also, a combination of these policies may help when international and domestic considerations are both significant. For instance and as already mentioned, domestic authorities may be reluctant to surrender monetary autonomy by shadowing foreign financial conditions exactly. In many cases, they may rely on unsterilized intervention to smooth the exchange rate but raise reserve requirements to cushion the net effect 
on the domestic money stock (Reinhart and Reinhart, 1999). As long as required reserves do not pay a competitive interest rate, however, reserve requirements are a tax on the banking system. Changes in that tax can have real effects, including on the exchange rate, depending on the incidence of the tax.

\section{Some Evidence on the Actions of Emerging Market Authorities}

We read theory as suggesting that authorities in emerging market economies have tools at their disposal to trim an appreciation of their currency. We read the evident smoothness of many exchange rates as suggestive of them using at least some of those tools. In this section, we present evidence that they use those tools in part to insulate the domestic economy from some of the consequences of these actions regarding the exchange rate.

As can be seen in Figure 2, emerging market economies have been accumulating reserves on a massive scale. According to the International Monetary Fund, international reserves of the group "Other Emerging Market Economies," which includes China and India, are set to increase $\$ 3 / 4$ trillion in each of the next few years. Those reserves could be increasing through sterilized intervention attempting to hold up the risk premium by changing relative asset stocks or unsterilized intervention that keeps the nominal interest rate low by allowing foreign reserves to bloat the domestic money stock. If it were the latter, we would expect to see an association between the domestic money stock and foreign exchange reserves. 


\section{Figure 2}

Annual Accumulation of Foreign Exchange Reserves,

Other Emerging Market and Developing Economies

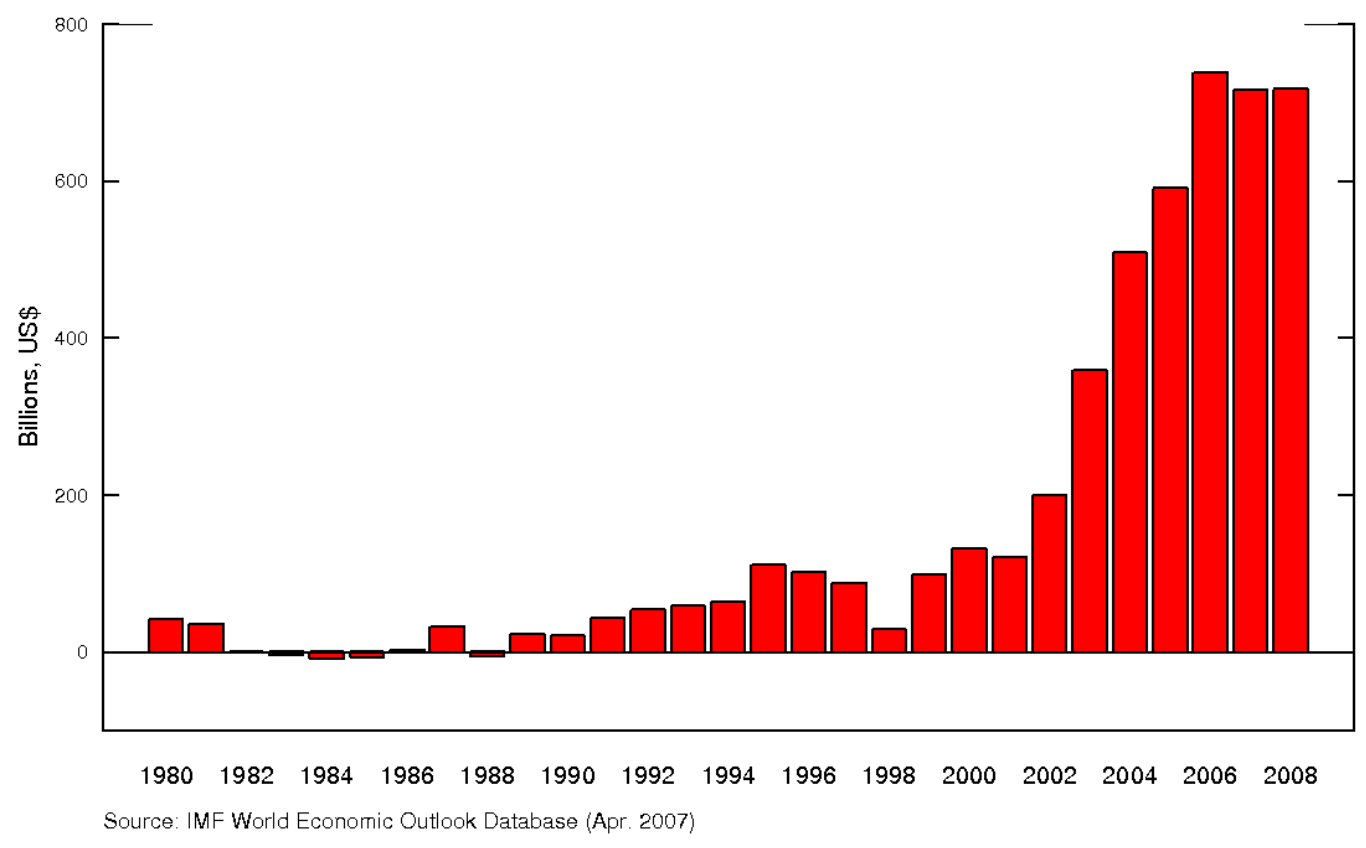

To investigate the matter, we gathered annual data on international reserves and the domestic money stock for thirty nonindustrial economies. The upper panel of Figure 3 plots the pairwise observations of the percent changes in the narrow domestic money stock along the vertical axis and the percent change in international reserves along the horizontal axis. Ordinary-least-squares regression lines are drawn through each year's worth of observations. Quite clearly, international reserves did not leave a material imprint on the domestic money stock in the early years of this decade. More recently, though, those regression lines point more distinctly upward. 
Figure 3

Changes in Reserves and Money, 2000-2006, Emerging Market Countries

Changes in Reserves and Money*

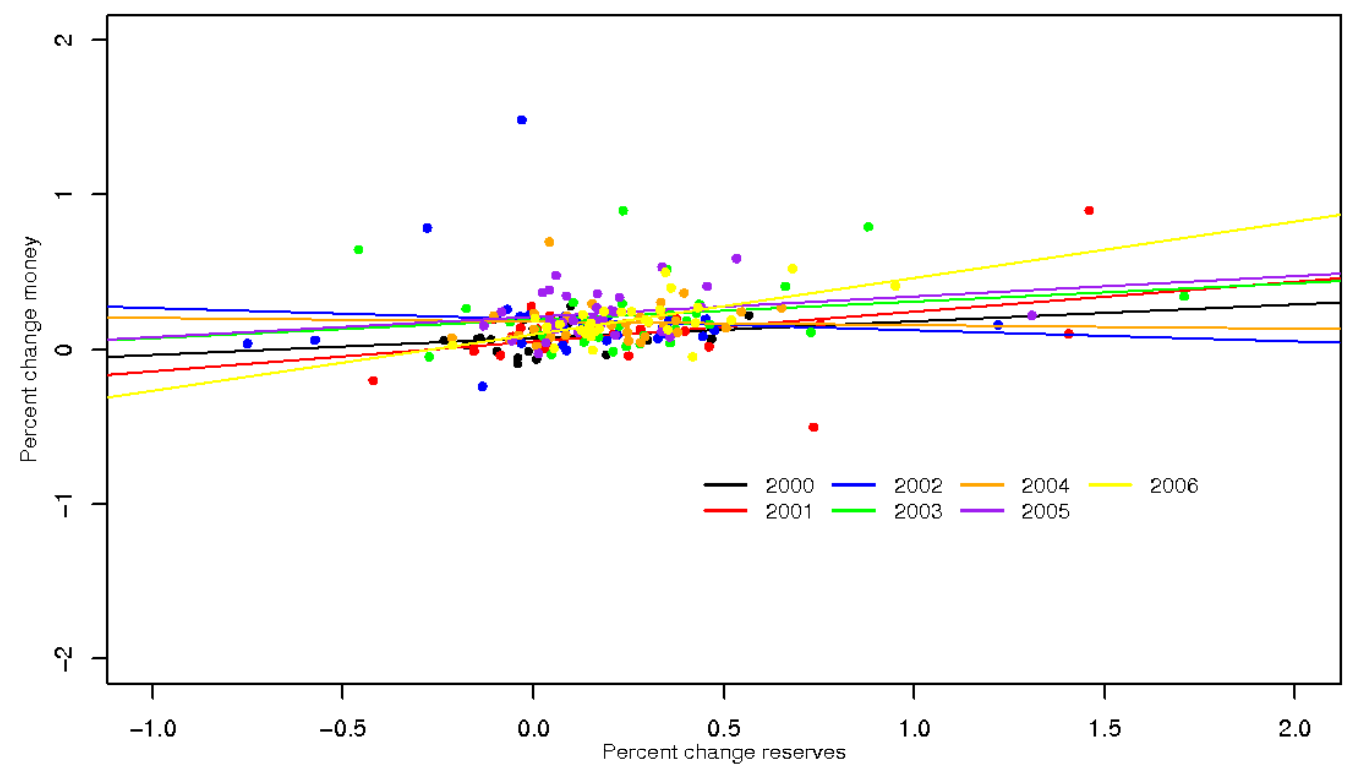

Money Elasticity with Respect to Reserves ${ }^{\star}$

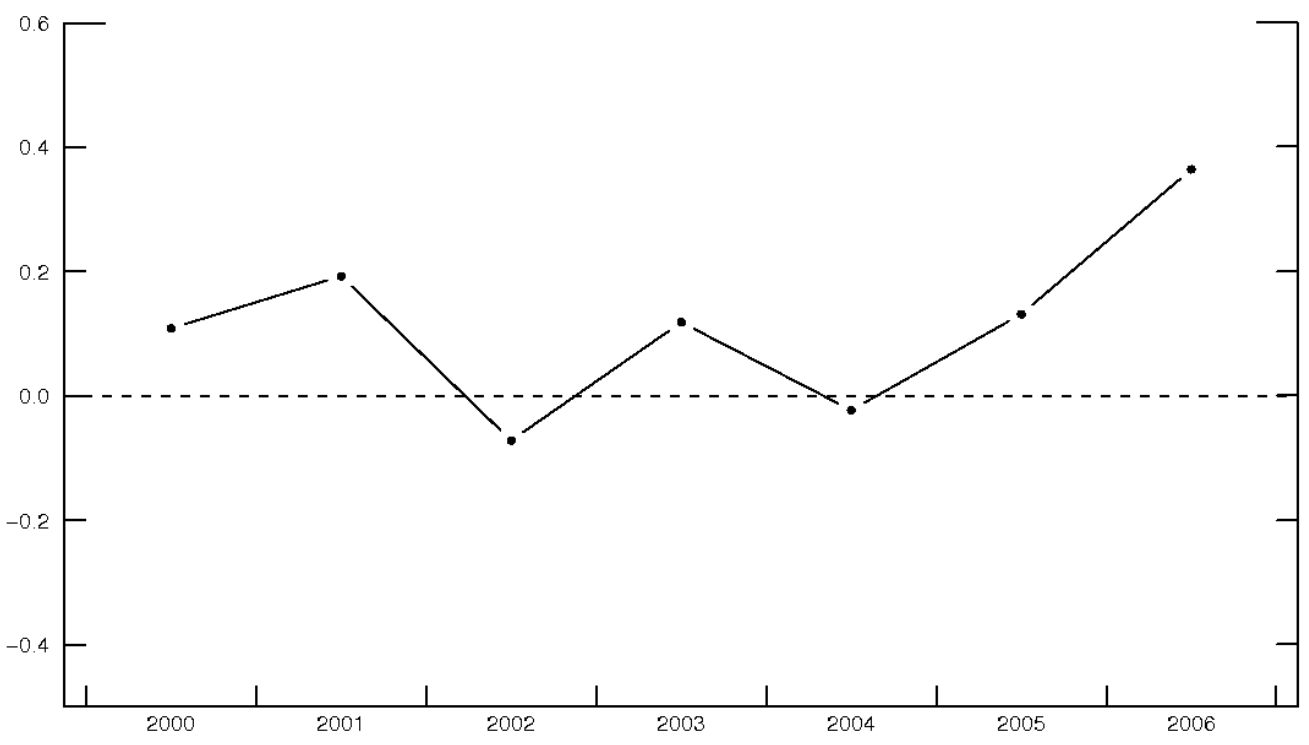

*Countries used in the analysis were Argentina, Bahamas, Barbados, Bosnia, Bulgaria, China, Colombia, Costa Rica, Dorninican Republic, Estonia, Honduras, Hungary, India, Jamaica, Korea, Kuwait, Latvia, Lebanon, Lithuania, Macedonia, Malta, Oman, Pakistan, Peru, Philippines, Poland, Qatar, Russia. Sinaadore. Trinidad. and Uruauav. Data for monev are from line 34, and for reserves from line 11 . d. in 'International Financial Statistics' (IMF) 
This tendency can be seen more distinctly in the bottom panel, which plots the slope coefficient from these regressions over time, which can be interpreted as the elasticity of the domestic money supply to international reserves. This elasticity has often been close to zero. In the most recent years, though, authorities apparently have found it difficult to offset their massive purchases and the coefficient has drifted up.

Why does the direct policy tool that so often occupies center stage in theoretical models—changes in reserves—seem to have so little domestic consequence? The shallowness of some of these domestic financial markets cast doubt on the explanation that this is evidence of sterilization. Rather, it may signal that authorities use some of the other tools at hand, importantly including reserve requirements, to offset the effects of their unsterilized intervention. To shed light on the issue, we amassed information on official actions directed toward the exchange rate in more than one-hundred countries over the past decade from a variety of sources, paying particular, but not exclusive, attention to reserve requirements. The list of countries for which some information is available is given in Figure 4. The detailed results are relegated to on-line worksheet, but certain regularities are worth highlighting. ${ }^{7}$

\footnotetext{
7 The worksheet and accompanying explanatory information prepared by April Gifford are available at http://www.wam.umd.edu/ creinhar/.
} 
Figure 4

Countries and Economic Unions in the Sample

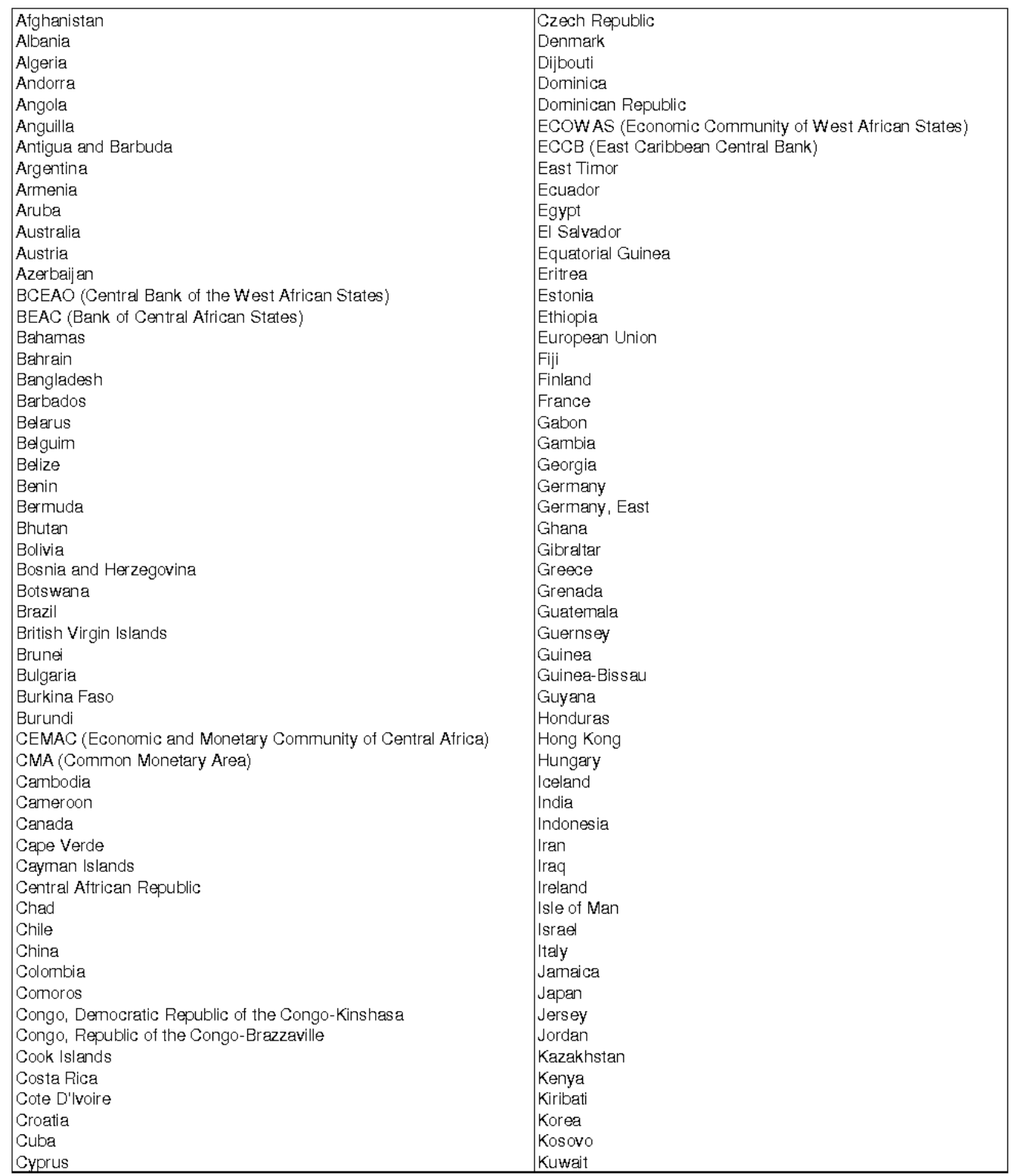


Figure 4 (continued)

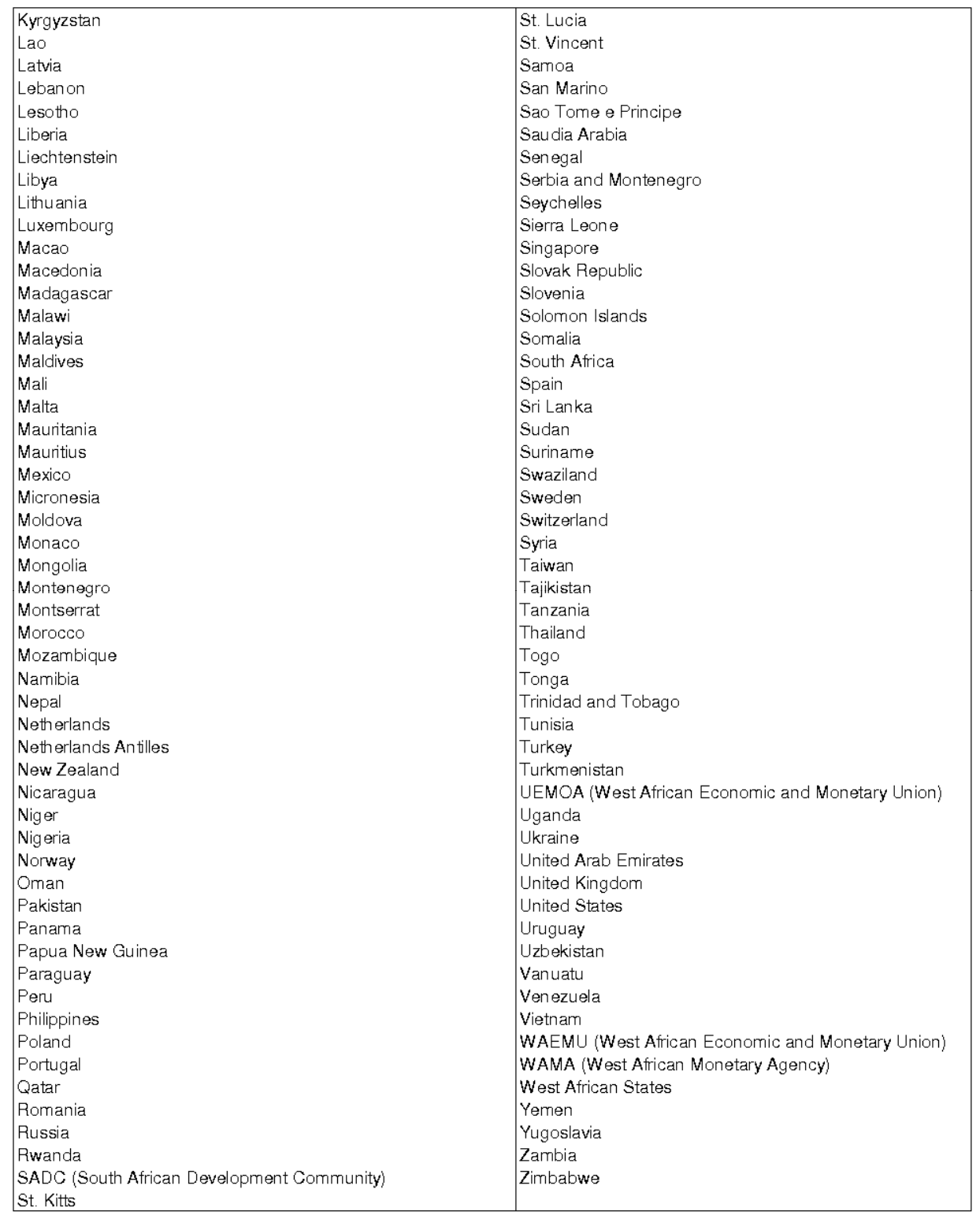


The range of experience is considerable and changes in policy can be quite nuanced. Countries as varied as Croatia, South Korea, and Vietnam raised reserve requirements in the past few years to restrain the expansion of domestic credit. At the head of the league table, though, is the People's Bank of China, which upped the required reserve ratio six times in the first seven months of 2007 to blunt the effects of swelling international reserves on the domestic money stock. In many countries, more nuanced policy adjustments are also possible, in that reserve requirements often differ by the type, maturity, and currency composition of deposits.

The apparatus of reserve requirements also apparently has an options value to authorities even if actual requirements have gone untouched for some time. For example, a recent report of the Reserve Bank of India held that “... it is necessary to retain the flexibility of using reserve requirements as and when necessary." ${ }^{\prime}$ In recent years, international financial institutions hve also come to the recognition that such tools may prove useful. As one example, among the preliminary conclusions in the International Monetary Fund's Article IV consultation with Kazakh officials in 2006 was

... the National Bank of Kazakhstan (NBK) will need to move quickly to soak up liquidity to slow the pace of credit expansion. This can be achieved by increasing the interest rate paid on bank deposits to at least

\footnotetext{
8 Original sources for this and what follows are provided in the worksheet.
} 
international levels and by broadening the coverage of reserve requirements to include all liabilities, which should also help slow external borrowing. In addition, consideration should also be given to a moderate and temporary increase in reserve requirements to aid in mopping up liquidity.

Some national authorities, however, have eschewed the use of reserve requirements, including Australia, Denmark, El Salvador, Hong Kong, Sweden, and Switzerland. Even less interventionist are the handful of economies that have given up independent monetary policy, including those that have adopted a currency board, such as Brunei and Hong Kong, and the completely dollarized Ecuador.

While the list stresses changes in reserve requirements, also included are controls on capital inflows, on capital outflows, and changes in official exchange rate bands. The variety of experience eludes simple summary, suggesting that researchers should reflect the range of alternative policies in modeling.

\section{Conclusion}

The experience of emerging market economies over the past decade offers many governmental experiments with influencing the foreign exchange market, but unfortunately few of them are controlled experiments. We can trace associations among variables—say, low foreign interest rates occur in tandem with capital inflows 
and increased taxes on those inflows. The extent to which one produced the other, however, is difficult to ascertain.

We take the variety of official actions to be evidence of:

- Distaste for exchange rate appreciation when capital flows in;

- Belief that policy tools can be effective; and

- Recognition that no single tool is completely effective.

In addition, authorities seem reluctant to be bound by the iron triangle of international finance that holds only two of the following three can be achieved: freely mobile capital, fixed exchange rates, and monetary autonomy. Even as investors direct capital internationally with increasing vigor, authorities look for ways to train some measure of monetary control while delivering a stable exchange rate. When global capital flows in, the preference for relatively stable exchange rates often necessitates accumulating reserves. Important among the tools to blunt the consequences on domestic liquidity of that reserve build-up are reserve requirements, which are often seen as having the advantage of potentially being tailored to an instrument's type, maturity, and currency denomination, but other tools are also in the arsenal. 


\section{References}

Bartolini, Leonardo and Allan Drazen, "Current Account Liberalization as a Signal," The American Economic Review, 87, No. 1. (Mar., 1997), pp. 138-154.

Guillermo A. Calvo, Leonardo Leiderman, and Carmen M. Reinhart, "Inflows of Capital to Developing Countries in the 1990s," Journal of Economic Perspectives, 10, Spring 1996, no. 2, pp. 123-139.

Calvo, Guillermo A. and Carmen M. Reinhart, "Fear of Floating," Quarterly Journal of Economics, Vol. CXVII No. 2, May 2002, 379-408.

Chen, Y. and Rogoff, Kenneth, "Commodity Currencies and Empirical Exchange Rate Puzzles,” DNB Staff Reports, No. 76, 2002.

Dominguez, Kathryn M. and Frankel, Jeffrey A., "Does Foreign Exchange Intervention Matter? The Portfolio Effect", The American Economic Review, 83, 1993, 1356-59.

Edwards, Sebastian, "How Effective are Capital Controls?" Journal of Economic Perspectives, 13(4), Fall 1999, 65-84.

Frankel, Jeffrey A. and Okongwu, Chudozie, "Liberalized Portfolio Capital Inflows in Emerging Markets: Sterilization, Expectations, and the Incompleteness of Interest Rate Convergence", International Journal of Finance and Economics, 1, 1996, 1-23.

Kaminsky, Graciela L. and Lewis, Karen K., "Does Foreign Exchange Intervention Signal Future Monetary Policy?”, Journal of Monetary Economics, 37, 1996, 285-312.

Labán, Raúl and Felipe Larraín, "Can a Liberalization of Capital Outflows Increase Net Capital Inflows?” Universad Catolica de Chile Working Paper no. 155, 1993.

Mussa, Michael, “The Role of Intervention,” Group of Thirty Occasional Paper no. 6, 1981.

Reinhart, Vincent R., "How the Machinery of International Finance Runs with Sand in its Wheels," Review of International Economics, 8(1), 2000, 74-85.

Reinhart, Carmen and Vincent R. Reinhart "Some Lessons for Policy Makers Who Deal with the Mixed Blessing of Capital Inflows," in Miles Kahler, ed. Capital Flows and Financial Crises, Council on Foreign Relations Book (Ithaca, NY: Cornell University Press, 1998), 93-127. 
Reinhart, Carmen and Vincent R. Reinhart, "On the Use of Reserve Requirements in Dealing with the Capital-Flow Problem," International Journal of Finance and Economics, 4(1), January 1999, 27-54.

Reinhart, Carmen and Vincent R. Reinhart, "What Hurts Most? G-3 Exchange Rate or Interest Rate Volatility," in Sebastian Edwards and Jeffrey Frankel, eds. Preventing Currency Crises in Emerging Markets (Chicago: University of Chicago Press for the National Bureau of Economic Research, 2002), 133-170.

Schadler, Susan, Carkovic, M, Bennett, A., and Khan, R., "Recent Experiences with Surges in Capital Inflows," IMF Occasional Paper number 108, 1993. 